\title{
Epidemiology of pregnancies with unknown last menstrual period
}

\author{
P BUEKENS, P DELVOYE, E WOLLAST, AND C ROBYN \\ From the Centre d'Informatique en Gynécologie et Obstétrique (CIGO), Free University of Brussels (ULB), \\ Ecole de Santé Publique, 1070 Brussels, Belgium
}

SUMMARY A group of women with unknown last menstrual period was studied representing 16\% of a total of 22404 pregnant women recorded using a common perinatal form. Unknown menstrual period is associated with high rates of low birth weight and with low socioeconomic and sociodemographic status. Such characteristics are also associated with a high rate of preterm deliveries. Thus any possible bias introduced in studies of prematurity by ignoring the group of women with unknown last menstrual period should be carefully checked.

Evaluation of the gestational age is critical for the study of prematurity. The date of the last menstrual period (LMP) is often used as a reference but as much as $30 \%$ of the sample may not know it. ${ }^{1}$ Few authors give details about this group of unknowns, which generally are not included in the analysis of their data, thereby casting doubt on the representativeness of their sample. In this paper we study the relation between the proportion of unknown LMP and sociodemographic and socioeconomic indicators. We assess the bias introduced when the group of women with unknown LMP is ignored.

\section{Materials and methods}

Between 1974 and 1978, 22404 single deliveries were studied in 10 Belgian hospitals using a common perinatal record. The date of LMP was registered at the first interview.

Newborns whose birth weight of $1000-2500 \mathrm{~g}$ were considered as low birthweight infants.

The sociodemographic indicators used were age of the mother, parity, nationality, and marital status. The socioeconomic indicators studied were educational level of the mother, professional status of the father (or that of the mother when the father was not working), abandonment of the newborn by the mother, height of the mother, ${ }^{2}$ and her age at the menarche.

Statistical significance has been evaluated using the chi-square test of the exact test of significance for correlation coefficients. $^{3}$

\section{Results}

The proportion of unknown LMP is $16 \%$; the proportion of low birth weight is $9 \%$ in the group with unknown LMP and $6.5 \%$ in the group with known LMP $(p<0.01)$.

Relationship between the rate of unknown last menstrual period and sociodemographic and socioeconomic indicators

\begin{tabular}{|c|c|c|c|}
\hline & No & $\begin{array}{l}\text { Unknown last } \\
\text { menstrual } \\
\text { period (\%) }\end{array}$ & $\begin{array}{l}\text { Statistical } \\
\text { significance }\end{array}$ \\
\hline $\begin{array}{l}\text { Age of mother } \\
15-19 \\
25-29 \\
35-44\end{array}$ & $\begin{array}{r}498 \\
6062 \\
1228\end{array}$ & $\begin{array}{l}16 \cdot 8 \\
11 \cdot 7 \\
17 \cdot 2\end{array}$ & $* * *$ \\
\hline $\begin{array}{l}\text { Nationality: } \\
\text { North African } \\
\text { Belgian }\end{array}$ & $\begin{array}{r}2048 \\
15920\end{array}$ & $\begin{array}{l}52.2 \\
10.7\end{array}$ & $* * *$ \\
\hline $\begin{array}{l}\text { Marital status: } \\
\text { Unmarried } \\
\text { Married }\end{array}$ & $\begin{array}{r}2147 \\
18355\end{array}$ & $\begin{array}{l}24 \cdot 9 \\
15 \cdot 3\end{array}$ & $* *$ \\
\hline $\begin{array}{l}\text { Educational level: } \\
\text { Illiterate } \\
\text { Other }\end{array}$ & $\begin{array}{r}454 \\
10847\end{array}$ & $\begin{array}{r}28.4 \\
6.7\end{array}$ & $* * *$ \\
\hline $\begin{array}{l}\text { Professional status: } \\
\text { Workers } \\
\text { Other professions }\end{array}$ & $\begin{array}{l}9069 \\
8067\end{array}$ & $\begin{array}{r}16 \cdot 5 \\
7 \cdot 2\end{array}$ & $* * *$ \\
\hline $\begin{array}{l}\text { Abandoned child: } \\
\text { Yes } \\
\text { No }\end{array}$ & $\begin{array}{r}118 \\
20525\end{array}$ & $\begin{array}{l}40 \cdot 0 \\
15 \cdot 5\end{array}$ & $* * *$ \\
\hline
\end{tabular}


The table summarises the relation between the proportion of unknown LMP and several indicators. There is a U-shaped relation between the proportion of unknown LMP and the age of the mother. There is a significant correlation $(r=0.99$ for $6 \mathrm{df}$ : $\mathrm{p}<0.01)$ between the proportion of unknown LMP and parity: it varies from $12 \%$ in primiparae to $41.8 \%$ in women with parity eight or more. The proportion of unknown LMP is high in North Africans, in the unmarried, in illiterates, and in women with low professional status. It is also high in the group of women who decide to abandon their newborns. There is an inverted relation $(\mathrm{r}=-0.985$ for $8 \mathrm{df}$ : $p<0.01)$ between the proportion of unknown LMP and the height of the mother: it varies from $19.2 \%$ in women measuring $140-144 \mathrm{~cm}$ to $8.3 \%$ in women measuring more than $185 \mathrm{~cm}$. Finally, there is a significant $(r=0.93$ for $6 \mathrm{df}: p<0.01)$ positive correlation between the proportion of unknown LMP and the age at menarche: a menarche at age 11 is associated with $7.7 \%$ of unknown LMP whereas a menarche at 18 or more is associated with $21.4 \%$ of unknown LMP.

\section{Discussion}

The data reported here indicate that the populations of women with known and unknown LMP differ. Firstly, women who do not know their LMP have more low birthweight newborns. This could result from the poor sociodemographic and socioeconomic status of the group of women with unknown LMP; women under 18 or over 30 , high parity, short stature, immigrants, low educational level, unmarried, low professional status, and unwanted pregnancies. The significant correlation between age at menarche and rate of unknown LMP could also be explained by the fact that late menarche is more frequent in low socioeconomic groups. ${ }^{4}$ Others have reported similar relations between socioeconomic factors and the group with unknown LMP. In an analysis of 52004 single births in Aberdeen Thomson et al found a linear relation between parity and the proportion of unknown gestational age. ${ }^{5}$ In the USA $7.5 \%$ of the white pregnant women but $15.5 \%$ of the black did not know their LMP. ${ }^{6}$ In a study on prematurity Hoffman has shown three possible types of bias': the proportion of unknown gestational age was higher in the south and north east of the United States, in the non-metropolitan areas, and among the black population.
Finally, many authors have shown a strong relation between prematurity and low sociodemographic and socioeconomic status. ${ }^{289}$ Thus a low social status is associated with a high preterm rate and with a high rate of unknown LMP. Deleting the group with unknown LMP will affect the accuracy of the estimation of the rate of preterm more in the group of low social status than in the group with high social status. This should be taken into account when interpretating the results of studies on prematurity. Thus we propose that such studies should include a detailed analysis of the distribution of the women with unknown gestational age for each selected indicator.

P Buekens is Aspirant du Fonds National Belge de la Recherche Scientifique.

\section{References}

${ }^{1}$ Hoffman HJ, Stark ChR, Lundin FE, Ashbrook JP. Analysis of birth weight, gestational age, and fetal viability, US births, 1968. Obstet Gynecol Surv 1974; 29: $651-81$.

${ }^{2}$ Garn SM, Shaw HA, McCabe KD. Effect of socioeconomic status and race on weight-defined and gestational prematurity in the United States. In: Reed DM, Stanley FJ, eds. The epidemiology of prematurity. Baltimore: Urban and Schwarzenberg, 1977: 127-43.

${ }^{3}$ Fisher D, Yates F. Statistical tables for biological, agricultural and medical research. Edinburgh: Oliver and Boyd, 1957: 59.

${ }^{4}$ Levy A. Décalage séculaire et puberté. Ann Pédiat 1980; 27: 547-52.

${ }^{5}$ Thomson AM, Billewicz WZ, Hytten FE. The assessment of fetal growth. Journal of Obstetrics and Gynaecology of the British Commonwealth 1968; 75: 903-16.

${ }^{6}$ Department of Health Education and Welfare. Factors associated with low birth weights USA 1976. Washington: DHEW, 1980; (DHEW publications NO (PHS) 80-1915).

${ }^{7}$ Fedrick J, Anderson A. Factors associated with spontaneous pre-term birth. BrJ Obstet Gynaecol 1976; 83: 342-50.

${ }^{8}$ Papiernik E, Kaminski M. Multifactorial study of the risk of prematurity at 32 weeks of gestation. J Perinat Med $1974 ; 2: 30-6$.

${ }^{9}$ Kaltreider F, Kohl S. Epidemiology of preterm delivery. Clin Obstet Gynecol 1980; 23: 17-31. 